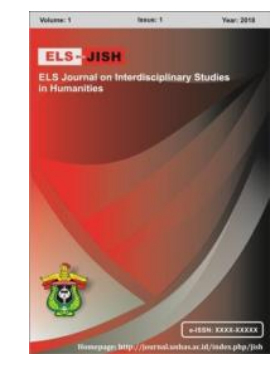

ELS-JISH

ELS Journal on Interdisciplinary Studies on Humanities

Volume 3 Issue 1, 2020

ISSN (print) : 2621-0843

ISSN (online) : 2621-0835

Homepage : http://journal.unhas.ac.id/index.php/jish

\title{
Teacher Professional Development: The Story of English Teacher's Beliefs and Practices
}

\author{
Septhina Shinta Sari ${ }^{1}$, Joko Nurkamto ${ }^{2}$, Dewi Rochsantiningsih ${ }^{3}$ \\ 1'septhinashinta@student.uns.ac.id
}

\begin{abstract}
Teacher professional development is often seen as the key to powerful education improvement. Therefore, teachers are expected to experience continuous professional development to keep abreast with the endless change taking place in the education routines. This study revealed the teacher's beliefs and practices regarding with teacher professional development activities. Using qualitative study, mainly through written guided reflection and interview, this investigation resulted in two important findings. The first dealt with the teacher's strong and positive beliefs toward teacher professional development activities and the other revealed the teacher's exemplary practices. Hence, this research gives the implication for the teachers to always be involved in life-long endeavor to maintain the professionalism.
\end{abstract}

Keywords: Teacher Professional Development, Teacher's Beliefs, Teacher's Practices.

How to cite: Sari, S.S., et. al. (2020). Teacher Professional Development: The Story of English Teacher's Beliefs and Practices. ELS Journal on Interdisciplinary Studies in Humanities, 3(1), 150-157. DOI: http://dx.doi.org/10.34050/els-jish.v3i1.9313

\section{Introduction}

Teacher professional development (here after called as TPD) is teachers' activity of learning, that is how they learn to learn and how they apply their knowledge in practice to support students' learning. It is about teachers' process of obtaining experience and transforming their understanding into practice for the benefit of their students' growth (Avalos, 2011).

In teaching language, there is a medium that provides a knowledge which related with the subject. According to Rahman (2017), the main criteria for selecting suitable literary texts are stressed on the underlying reasons and criteria for the level of the learners appropriately. Moreover, literature and the teaching of language skills can contribute each other.

TPD can serve some objectives including: to update teachers' knowledge of a subject in light of recent advances in the area, to update teachers' skills, attitudes and approaches in light of the development of new teaching techniques and objectives, new circumstances and new educational research, to enable individuals to apply changes made to curricula or other aspects of

1,2,3 Universitas Sebelas Maret, Indonesia 
teaching practice, to enable schools to develop and apply new strategies concerning the curriculum and other aspects of teaching practice, to exchange information and expertise among teachers, and to help weaker teachers become more effective (OECD, 2009).

Teacher professional development (hereafter TPD) can be provided in various ways, ranging from the formal to the informal. TPD is both an intellectual and personal attempt which needs not only involvement with new and different ideas about education, applying new activities and developing classroom practice, but also an emotional response since personal beliefs are challenged (Girvan, Conneely, \& Tangney, 2016). The activities in TPD can range from formal, structured topic-specific seminars given on in-service days, to everyday, informal discussions with other teachers about instruction techniques, embedded in teachers' everyday work lives (Desimone, 2009).

Professional development for teachers can take many forms, including university courses, local and national conferences, workshops, and specialized institutions. OECD mentioned that TPD could be courses, workshops or formal qualification programs, through collaboration between schools or teachers across schools (e.g. observational visits to other schools or teacher networks) or within the schools in which teachers work (OECD, 2009). According to Little, TPD may cover activities such as workshops, local and national conferences, college courses, special institutes, and centers (Little, 1993).

In Indonesian context, TPD is also conducted by employing a top-down approach in which teachers as the participants are not involved in the design and preparation. Participation in TPD activities depends on the availability of the programs and the rotation in school (Rochsantiningsih, 2005). Besides, nowadays teachers tend to be busy with some administrative tasks. Their heavy workload restrains them from initiating PD activities from themselves. A recent study reported that Indonesian teachers had enough opportunity to develop professionally but not everyone took advantages of this (Cirocki \& Farrell, 2019).

These problematic issues related to TPD are further compounded by the fact that, within English as a foreign language (EFL) teaching contexts, little is known about how EFL teachers interpret his/her TPD activities and how his/her cognition is reflected in teaching practices. Research investigating these questions could provide insight and guidance for providing effective TPD design.

This research tries to scrutinize EFL teacher's beliefs and practices regarding TPD. This is important to do since some studies analyzing teacher's beliefs and practices related to TPD need to be continuously done. Further investigation is really needed to reveal what actually EFL teacher perceives about TPD and how this perception is actualized into his/her daily teaching practices. Considering those reasons, the writer raises the following research questions:

1. What beliefs do EFL teachers have regarding with their TPD?

2. How do EFL teachers reflect their beliefs of TPD in teaching practice? 


\section{TPD and Teachers' Beliefs and Practices}

Beliefs is a proposition which someone holds consciously or unconsciously, which he considers it as true, so that it guides his thought and behaviors (Borg, 2001). The teacher's beliefs play important roles in educational process. It may decide how teachers view English, how they decide the teaching methods, and how they deal with challenges in their daily professional life and to their process of shaping students' learning, motivation and achievement.

Teachers' practices are influenced by their beliefs. Teachers themselves need to conceptualize and experience the relevance in their practice (Graves, 2009). It is important to know what language teachers do and what cognition beliefs, knowledge, thoughts - underpins their behaviour, because there is a direct relationship between cognition and practice in language teaching (Borg, 2001). There are two ways of thinking about relationships and practice: application of theory and theorizing in practice. The application of theory involves making connections between concepts, information and theories; the theorizing of practice on the other hand, involves reflecting on practice and developing an understanding of its underlying meaning in order to better understand the nature of language teaching and learning (Burn \& Richard, 2009, Cirocki \& Farrell, 2019).

Based on the framework proposed by Ingvarson et al., teachers' practice means that their attitude, habit, and daily practice in teaching the students. The indicators are that they:

- create clearer relationship between their teaching objectives and classroom activities;

- $\quad$ handle classroom management and activities more completely;

- employ more active teaching and learning techniques and strategies appropriate to the content that they teach;

- $\quad$ employ more effective teaching and learning strategies appropriate to the classroom context;

- employ teaching and learning strategies that are more challenging and engaging;

- $\quad$ are better able to meet the individual learning needs of their students;

- $\quad$ link assessment into the teaching and learning cycle more effectively;

- $\quad$ supply more effective feedback to their students to support their learning;

- $\quad$ engage students in higher order thinking;

- access and use materials and resources more effectively (Ingvarson, Meiers \& Beavis, 1998)

Professional development is defined as activities that develop an individual's skills, knowledge, expertise and other characteristics as a teacher (OECD, 2009). It is a lifelong endeavor, a way of being, and a perspective on how one practices as well the practice itself (Wong in Stroupe \& Kimura, 2013). Teachers' CPD should improve teacher quality and teaching practices (De Vries, S. Van de Grift, 2012). Teacher development is a term used to characterize a process of continuing intellectual, observational, and attitudinal growth of teachers (Wong in Stroupe \& Kimura, 2013). In other words, teacher 
development is considered lifelong and continual learning done by teachers to trigger changes in teachers' teaching practice that lead to improved student learning outcomes

\section{Method}

This research is a qualitative research which used the case study as a research design. Case study research is an empirical inquiry that investigate a contemporary phenomenon within its real-life context; when the boundaries between phenomenon and context are not clearly evident; and in which multiple sources of evidence are used (Yin, 2018). This method was chosen because the researchers found a unique phenomenon at the observed school. This research had been carried out at one of high schools in Surakarta.

The participant of this study was one English teacher who have been teaching English for almost 14 years. She has been involving in some TPD activities for years. She graduated from the English department in one of the private universities in Surakarta. The participant's name is pseudonym, that is TR refers to the participant.

Written guided reflection and interview were carried out by the researchers at the school. Firstly, the participant was asked to answer some guided questions. The next, interview was done and digitally recorded and transcribed. These two data collections were designed to obtain data from the participant about her beliefs and practices regarding with her CPD activities.

The data of this study will be analyzed using interactive models. There are four steps in interactive model namely data collection, data reduction, data display, and conclusions. The steps are presented in figure 1

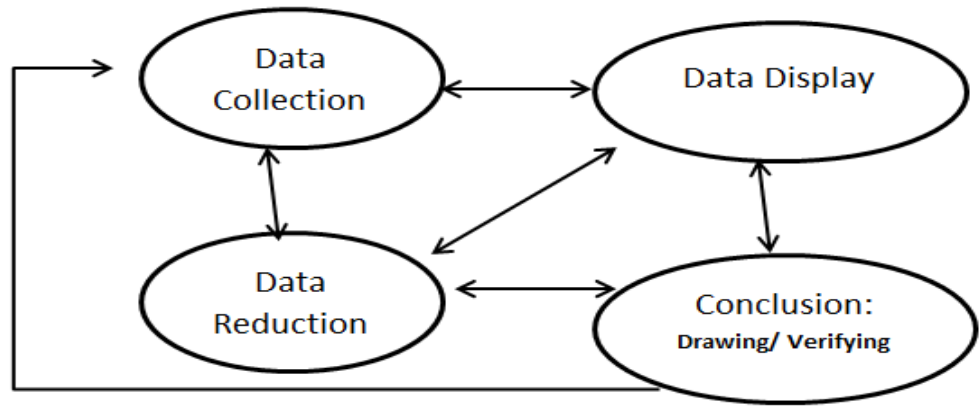

Figure 1. The interactive model of qualitative data analysis

(Miles, Huberman, \& Saldana, 2014)

\section{Findings and Discussion}

This section presents findings related to teacher's beliefs and practices regarding with her TPD activities. The information obtained from written guided reflection and interview is displayed in this section.

\subsection{Teacher's Beliefs of TPD}

In this section, the researchers asked about the concept and its importance of TPD, some TPD activities the teacher has accomplished, and the impact on students' learning outcomes. From the result of the written guided reflection and interview, there are some essential parts revealed then. 


\subsubsection{The Concept and Importance of TPD}

TR viewed TPD as meaningful and substantial part of teacher professionalism. She perceived the concept of TPD firstly from the workshop conducted by the teachers' community in her city. Then, she autonomously looked for further information about it, and tried to apply what she understood through her teaching routines. She confirmed that TPD is important activity to maintain her knowledge, skill, and the most crucial point to be underlined is TPD must improve students' learning outcome and positive attitude toward learning. These findings are in line with the motions proposed by the previous experts that TPD is activity used to characterize a process of continuing intellectual, observational, and attitudinal growth of teachers (Wong in Stroupe \& Kimura, 2013). Other expert also stated the ultimate goal of teacher development is to make the betterment of students' learning (Guskey, 2002).

\subsubsection{Some TPD Activities}

There were some activities which the teacher had joined, range through formal and informal ones. Attending seminars, workshops, and conferences, writing some articles and best practices in education field, and keeping an everyday teaching journal were some TPD activities the teacher had conducted in the last three years. Teacher TR confirmed that those activities were aimed at upgrading skills due to changes in society, obtaining new knowledge, and maintaining one's career as a professional teacher. These purposes also agree with the frameworks about activities and the reasons of TPD proposed by Wong in Stroupe \& Kimura (2013). Below is the complete explanation related to activities in TPD and the reasons why teachers tend to do them.

Table 1. Reasons for engaging in CPD Activities

\begin{tabular}{|c|c|c|}
\hline No & Reasons for Engaging in CPD & PD activities \\
\hline 1. & $\begin{array}{l}\text { To raise awareness of teachers' } \\
\text { strengths and weaknesses }\end{array}$ & $\begin{array}{l}\text { 1. Keep a journal and reflect on } \\
\text { teaching } \\
\text { 2. Learn a new language } \\
\text { 3. Record and view one's teaching } \\
\text { 4. Be observed by a peer } \\
\text { 5. Observe other teachers } \\
\text { 6. Compile a portfolio } \\
\text { 7. Engage in team teaching } \\
\text { 8. Find a mentor } \\
\text { 9. Engage in action research } \\
\text { 10. Survey students on one's teaching }\end{array}$ \\
\hline & To acquire new knowledge & $\begin{array}{l}\text { 11. Attend a conference } \\
\text { 12. Read professional journals } \\
\text { 13. Become active in organizations } \\
\text { 14. Write a book review } \\
\text { 15. Write a textbook manual or textbook } \\
\text { 16. Become a reviewer of textbooks } \\
\text { 17. Enroll in an MA or PhD program } \\
\text { 18. Launch a teachers' reading group } \\
\text { 19. Teach a different or course, or in } \\
\text { different context }\end{array}$ \\
\hline 3. & To solve a particular problem & 20. Engage in a case study \\
\hline
\end{tabular}




\begin{tabular}{ll}
\hline & 21. Interview colleagues \\
& 22. Present at a conference \\
& 23. Analyze a critical incident \\
& 24. Conduct an online survey \\
& 25. Join an online discussion list \\
& 26. Find related online resources \\
& 27. Start a special interest group \\
\hline 4. To upgrade skills due to changes & 28. Attend a workshop in desired area \\
in society or the field & 29. Find ways to learn from colleagues \\
& 30. Apply for grant to learn a skill \\
& 31. Take an online or distance course \\
\hline To advance one's career & 32. Get an advanced degree \\
& 33. Engage in and write up research \\
& 34. Write a chapter or a journal article \\
& 35. Co-write or edit a book \\
& 36. Apply for administrative positions \\
& 37. Seek out positions as a teacher \\
& 38. Develop a language course \\
& 39. Create a language program \\
& 40. Establish a language school \\
& 41. Volunteer to serve \\
\hline To find fulfillment in one's work & 42. Take a sabbatical \\
to prevent burnout & 43. Start a student scholarship fund \\
& 44. Organize a local conference \\
& 45. Volunteer in an organization \\
& 46. Engage in an international \\
& 47. Mentor other teachers \\
& 48. Teach less advantaged students \\
& 49. Start an ELT organization \\
& 50. Be an advocate for students \\
\hline &
\end{tabular}

Source: Wong in Stroupe \& Kimura (2013)

\subsubsection{The Impact of TPD on Students' Learning Outcomes}

The teacher TR stated that TPD contributed an intense impact on student learning outcomes especially on the aspect that students have less obstacles in understanding what teachers are being taught, are learning more intentionally, exhibit enhanced learning outcomes, and access and use materials and resources more effectively. She also confirmed that since she got positive impact after conducting TPD activities, being confident in delivering the materials in front of the class, her teaching practices showed a moderate impact on students' learning outcomes in terms of improved students' score, more confident skills in speaking and writing, and active engagement in learning activities. These findings are in line with the opinion stated by Ingvarson et al., 1998 that as a result of teacher joining TPD activities, students then: have less obstacles in understanding what they are being taught, are learning more intentionally, are more actively engaged in learning activities, exhibit enhanced learning outcomes, access and use materials and resources more effectively. 


\subsection{Teacher's Practices of TPD}

In this section, the researchers asked how she reflected her beliefs of TPD in teaching practice. She was asked how she applied the knowledge and skill she got from TPD activities. She answered that practice in teaching covered attitude, habit, and daily practice. She tried to applied the new knowledge she got by adjusting it to the class situation and school policy. The use of gadget, for example, students were strictly controlled by the school rules about when to use it and when not. She had to design the teaching scenario so that she still could apply the learning process by using gadget and digital technology. Other opinion was related to the issue of higher order thinking skills. She confirmed that she was challenged to apply the information she got from TPD activities to elevate her students' higher order thinking skills. These findings matched with the idea proposed by Ingvarson et al., (1998) that after conducting TPD activities, teachers are required to be able to: create clearer relationship between their teaching objectives and classroom activities, handle classroom management and activities more completely, employ more active teaching and learning techniques and strategies appropriate to the content that they teach, employ more effective teaching and learning strategies appropriate to the classroom context, employ teaching and learning strategies that are more challenging and engaging, meet the individual learning needs of their students, link assessment into the teaching and learning cycle more effectively, supply more effective feedback to their students to support their learning, engage students in higher order thinking, access and use materials and resources more effectively.

\section{Conclusion}

This paper was conducted to explore teacher's beliefs and practice of TPD. To reveal these motions, the researchers made use of written guided reflection and interview. The result showed that the teacher in this investigation exhibited strong and positive impact of the concept of TPD. It could be seen from the findings that she answered completely about the concept and importance of TPD. She also clearly mentioned and defined some reasons of joining those TPD activities and the impact of TPD on students' learning outcomes. Further, she also reflected her beliefs of TPD in everyday teaching practices by applying the knowledge and skill she got for TPD activities. These practices then could promote students' higher order thinking skills and enable students' access and use materials and resources more effectively. This research gives the implication for all EFL teachers to always be involved in lifelong endeavor to maintain the professionalism.

\section{Acknowledgments}

I would like to offer my special thanks to Prof. Joko Nurkamto and Ibu Dewi Rochsantiningsih for their invaluable and constructive suggestions during the writing process of this research. Their willingness to give their time so kindly has been very much appreciated. I would also like to extend my thanks to the participant Teacher TR for her willingness and cooperation during the process of collecting the data. 


\section{References}

Avalos, B. (2011). Teacher professional development in Teaching and Teacher Education over ten years q. Teaching and Teacher Education, 27(1), 1020. https://doi.org/10.1016/j.tate.2010.08.007

Borg, M. (2001). Key concepts in ELT. Teachers' beliefs. ELT Journal, 55(2), 186-188. https://doi.org/10.1093/elt/55.2.186

Burns, A., \& Richards, J. C. (2009). The Cambridge Guide to Second Language Teacher Education.

Cirocki, A., \& Farrell, T. S. C. (2019). Professional development of secondary school EFL teachers: Voices from Indonesia. System, 85, 102111. https://doi.org/10.1016/j.system.2019.102111

De Vries, S. Van de Grift, W. J. C. . and J. (2012). Teachers' beliefs and continuing professional development.

Desimone, L. M. (2009). Improving impact studies of teachers' professional development: Toward better conceptualizations and measures. Educational Researcher, 38(3), 181-199. https://doi.org/10.3102/0013189X08331140

Girvan, C., Conneely, C., \& Tangney, B. (2016). Extending experiential learning in teacher professional development. Teaching and Teacher Education, 58, 129-139. https://doi.org/10.1016/j.tate.2016.04.009

Guskey, T. (2002). Professional development and teacher change. Teachers and Teaching: Theory and Practice, 8(January 2013), 381.

Ingvarson, L., Meiers, M., \& Beavis, A. (1998). Evaluating the quality and impact of professional development programs. Acer Research Conference 2003, 28-34.

Little, J. W. (1993). Teachers' Professional Development in a Climate of Educational Reform. Educational Evaluation and Policy Analysis, 15(2), 129-151. https://doi.org/10.3102/01623737015002129

Miles, M. B., Huberman, M. A., \& Saldana, J. (2014). Qualitative Data Analysis: A Methods Sourcebook. SAGE Publications (Vol. 66).

OECD. (2009). Creating Effective Teaching and Learning Environments. Talis. https://doi.org/10.1787/9789264068780-en

Rahman, F. (2017). The Strategy of Teaching Literature through Languagebased Method: A Communicative Approach.

Rochsantiningsih, D. (2005). Enhancing Professional Development of Indonesian High School Teachers through Action Research, (February).

Stroupe, R., \& Kimura, K. (2013). Research and Practice in English Language Teaching in Asia. Research and Practice in English Language Teaching in Asia. https://doi.org/10.5746/leia/rpelta

Yin, Ro. K. (2018). Case Study Research and Applications: Designs and Methods. 